\title{
Creative Teaching as a Component of the New Standard-Based Curriculum in Ghana: Curriculum Rushed or Curriculum Planned?
}

\author{
Inuusah Mahama ${ }^{1 *}$ (D)
}

${ }^{1}$ Department of Counselling Psychology, University of Education, Winneba, GHANA

*Corresponding Author: imahama@uew.edu.gh

Citation: Mahama, I. (2022). Creative Teaching as a Component of the New Standard-Based Curriculum in Ghana: Curriculum Rushed or Curriculum Planned?. Mediterranean Journal of Social \& Behavioral Research, 6(1), 27-33. https://doi.org/10.30935/mjosbr/11569

\begin{abstract}
The study was about the creative nurturing behaviors of in-service teachers in Ghana. Using the descriptive crosssectional survey design, a sample of 768 (out of 1,321) in-service teachers were surveyed using online Google forms. The data for the study were collected with an adapted version of the Sharma and Sharma (2018) creativity nurturing behavior scale (15-items; $\alpha=.79$ ). The data were descriptively and inferentially analyzed. Overall, the study found that majority of respondents exhibited low levels of creativity nurturing behaviors. Specifically, most of the respondents had moderate levels of creative curiosity and creative motivation, but some respondents had low levels of creative abstractions and critical thinking. Again, the study revealed that male and female respondents did not differ in their creative nurturing behaviors. Finally, differences were not established in creativity nurturing behaviors of in-service teachers based on the experience. In-service teachers were found to have insufficient knowledge on creative teaching. Therefore, it was recommended that in-service teachers need to be re-trained in the core competent areas of the new standard-based curriculum.
\end{abstract}

Keywords: curriculum, creativity, teachers, teaching

Received: 2 Nov. 2021 Accepted: 30 Dec. 2021

\section{INTRODUCTION}

Globally, it is agreed that creativity is essential for social and economic progress, as well as for individuals' personal and professional fulfillment (Collard \& Looney, 2014). According to Collard and Looney (2014), in a knowledge society, creativity is required for advancement as work is carried out in nonpermanent project-oriented teams, with each team member taking on a large amount of responsibility. New situations and problem-solving methodologies must be learned regularly by individuals through creativity. The ability to tailor services and products to meet individual needs is increasing in individuals' personal lives. In addition to the economic motivations for encouraging creativity (Voogt \& Roblin, 2012), the reasons for re-igniting the fostering of creativity are considered as a social good, both on an individual and societal level (Beghetto \& Kaufman, 2010). So it should come as no surprise that creativity is seen as a top priority in education on all continents and that it is at the heart of the discussion about 21st century learning. As the Organisation for Economic Co-operation and Development (OECD) points out, it is critical to prepare students for the unknown: for jobs that do not yet exist, for technologies that have not yet been conceived, and for issues that have not yet been foreseen (OECD, 2009).
Furthermore, the OECD Innovation Strand places great emphasis on the development of creative abilities in children and young people around the world. Based on this, schools are required to teach and measure creativity in the future workforce, given the requirement for individuals with the ability to be creative in the workplace (Lee et al., 2004). The nurturing of creativity among students appears to be the sole responsibility of teachers because it is not only about teachers teaching techniques and in-service habits that are influenced by teachers' innovative behaviour, but it also has an impact on students' ability to come up with fresh and original ideas (Nemeržitski et al., 2013).

Education, especially in an age of computerization, standardization, accountability, and testing has had a tremendous influence on teachers and their professional practice (Hargreaves \& Shirley, 2009; Sahlberg, 2010). According to Sahlberg (2010), in-service teachers encounter two primary challenges in developing creativity and innovation in the classroom. First, they believe they are not original people, and second, even if they were to involve in more creative teaching events, it is school policies and measures that prohibit innovation and originality. Another barrier Sahlberg (2010) mentioned, is the standardization of teaching and learning, where the stress is placed on the standardization of assessment and preset consequences, which leads to a decline in collaboration between teachers and ultimately a decrease in innovation.

Doyle (2019) and Har and Abd-Razak (2017) note that it has long been recognized that teacher creativity plays a vital role in developing 
students to become imaginative and innovative in their lives. According to Baruah and Paulus (2019) and Karwowski et al. (2013), the promotion of teacher creativity and innovation is an important component in the teaching profession. Again, teachers with adequate creative abilities inure teacher-student interaction (Sawyer, 2012). In a similar vein, Davies et al. (2013) and Ucus and Acar (2018) opined that creativity in the classroom allows students to possess different expectations, engage in mutual respect, exhibit innovative conduct, flexibility, and conversations. Expatiating the essence of creativity in the classroom, Saibon et al. (2017) were of the view that teaching and learning processes based on traditional methods such as chalk and speak, one-way input delivery, and one-to-many interactions should be progressively changed into adopting and implementing innovative training. As part of 21st century teaching and learning objectives, improving and fostering creativity and critical thinking skills are imperative (Bloom \& Doss, 2019). This is so because creativity possesses the required impetus to arouse positive change in methodological practices that could spur teaching and learning into a lively and exciting learning community.

However, paucity of the literature shows that students' creative abilities are not nurtured in the teaching and learning environment because teachers appear to possess less knowledge in honing such natural potentials (Ahmadi et al., 2019; Beghetto, 2010; Bloom \& Doss, 2019; Fasko \& Rizza, 2019; Sawyer, 2010). According to Apak et al. (2021) and Karpudewan and Chong-Keat (2017), this trend might be a result of the fact that teaching and learning have continued to be traditional with a focus on rote memorization of facts that could curtail the identification of new ideas that could bring about positive economic transformation for various nations. The seeming lack of knowledge among teachers about the nurturing of creativity in the classroom defeats the assumption that 21 st century teaching and learning must enhance the change process of nursing a future workforce that is fortified with familiarity and abilities to face the ensuing global encounters (Karpudewan \& Meng, 2017). As a tricky construct, creativity defies a precise definition. Accordingly, creativity can be defined as mental ability, a process, and human behaviour (Andriopoulos, 2000). Dimensionally, creativity is of two facets: the notion of novelty (occurs in everyday life and possessed by everyone), and the notion of usefulness (referring to material or practical techniques of evaluating the value of new ideas (Shalley et al., 2004). Regarding this study, the creative nurturing behaviour of teachers is about their scaffolding attributes in guiding learners to become geniuses in their learning situations.

In Ghana, recent curriculum reform (New Standard-based Curriculum) in education has brought about an enormous call for creativity in learning. As part of the core competence areas (critical thinking and problem solving, creativity and innovation, communication and collaboration, cultural identity and global citizenship, personal development and leadership, as well as digital literacy) for students to achieve, the Government of Ghana included creativity and innovation and critical thinking and problem solving, which must be nurtured in students by in-service teachers (Ghana Education Service, 2019; Ministery of Education, 2018; National Council for Curriculum and Assessment [NaCCA], 2019). The curriculum reform placed a major responsibility on teachers to propagate the government drive of implementing the New Standardbased Curriculum. Before the implementation, some in-service teachers (kindergarten to primary six) were taken through the tenets of the new curriculum for five (5) days between $13^{\text {th }}$ to $19^{\text {th }}$ August 2019. Later, some other groups of in-service teachers (Junior High School 1 to Senior High School 1) were trained on the new curriculum between 11th to 15th January 2021 (Ghana Education Service, 2021; NaCCA, 2019).

Looking at the periods of training for both cohorts, the days appeared to be inadequate because of the extensive nature of the outlined content areas. However, in-service teachers were required to absorb every aspect of the competent areas within the short period for onward training on students. In creativity nurturing training, the ideal duration is two academic semesters (making up 140 credit hours) (Birdi, 2016; Ritter et al., 2020) but this was not the case in Ghana as the training that teachers were taken through could not have moved beyond the introductory aspects of creativity. This calls for concern as many in-service teachers given the mantle to implement the New Standard-based Curriculum might not be creative themselves because they may still be glued to the old or the objective and examination-based curriculum (Apau, 2021). Beghetto (2007) alleged that teachers trained using objective-based and examination-based curriculum prefer standardization over originality because it promotes duplication of concepts rather than understanding. Extant literature on creativity reveals teachers' unfavourable views towards behaviours and qualities that are commonly associated with creativity because they are not creative themselves (Kampylis et al., 2009). As a result, in-service teachers might not possess the required abilities to teach and coach their students to become creative and prepare for the ever-advancing technological world. This supports the fact that teachers who respect creativity are more likely to be creative, but their capacity to nurture students' creativity mostly depends on their level of training (Fasko, 2001).

Just like many educational curriculum reforms in Africa, the Ghanaian version was a top-down approach that denied teachers the opportunity to contribute their quota (Abudu, 2015; Okoth, 2016). However, these teachers are the only group required for curriculum execution in the educational landscape. The blame of inadequate mindset of teachers in creativity cannot be placed on the door-steps of the in-service teachers only but the creators (Government of Ghana, Ministry of Education, Ghana Education Service, and NaCCA) of the curriculum because of the perceived haste at which the curriculum was implemented. This perceived rush could deny teachers ample time to keep up with the entire curriculum package. Based on this circumstantial information, the current study sought to address the following question and hypotheses:

1. What is the level of creative nurturing behaviours among inservice teachers in Ghana?

2. H1: The creativity nurturing behavior of in-service teachers will not differ based on their biological segregation (gender).

3. $\mathbf{H}_{2}$ : The creativity-fostering behavior of in-service teachers will not differ based on their teaching experience.

\section{LITERATURE REVIEW}

Applying the main strategies of creativity, Cropley (1997) summarized the creativity fostering behavior of teachers as inspiring learners to learn autonomously, personally, applying supportive and social incorporation instruction styles, and inspiring them to take 
control of basic knowledge in diverse thinking skills or styles. Affirming the findings of this, Soh (2015) suggests that teachers should engage in creative nurturing behaviours as a legitimate response; when done at the appropriate time, it will invariably motivate students to work harder in the future.

Teacher creativity nurturing behaviour is further described in detail by Soh (2017), who identified some aspects of teacher behaviour that foster creativity. These aspects are autonomy, incorporation, inspiration, reflection, suppleness, valuation, interrogative, prospects, and displeasure. Instructional practice aimed at nurturing learners' creativity through precise behaviour and approaches, informed by their classroom proficiency, is defined as follows: being open to creative ideas and showing mastery over one's opinions and activities, as well as appreciating the freedom to think. Stone (2015) and Turner (2013) resolved that teachers' previous knowledge had no impact on their creativity nurturing conduct in the classroom while looking into the behaviour of teachers in the classroom. However, less experienced teachers demonstrated higher levels of creativity and novelty in the execution of e-learning activities compared to teachers with more experience, according to Loogma et al. (2012). In another study, it was found that although most teachers shared similar opinions on what makes good creative practice, the relationship between these beliefs and teacher instructional practice was not consistently observed, according to Gong et al. (2012). In similar vein, Snell (2013) discovered that disparities in instructors' levels of experience did not result in changes in their perceptions. However, the study by Al-Nouh et al. (2014) found that teachers' opinions about creativity in the classroom were good.

Teachers with less experience preferred creative thinking compared to their counterparts who were more experienced. Huang et al. (2019) found that the perceived usability of creative ideas by teachers by teachers and the creative behaviour of teachers were substantially related to the aim of teachers of teachers to involve themselves in creative teaching. Apak et al. (2021) conducted a study among 500 randomly selected high school teachers and analyzed the data using the one-way ANOVA test. They discovered that teachers with more than 20 years of teaching experience received higher mean scores than their less experienced counterparts. Those with more experience demonstrated greater creativity and originality than teachers with less experience. Despite inconsistent revelations, Dikici (2014) indicated that teacher experience in creative abilities played a role in shaping the relationship between thinking style and creative development.

A study by Davies et al. (2013) discovered that teachers' implicit beliefs affect their behaviours, and thus, their students' creativity. According to Chan and Yuen (2015), the concepts of creativity differ and vary between subcultures. To Hong et al. (2009), a study among Korean teachers revealed that they encouraged their students to be creative, as such students frequently had a high inherent wish for creative activity, and hold sophisticated attitudes about knowledge attainment. Teachers who held erroneous ideas about creativity experienced difficulties with creative learners (Aljughaiman \& Mowrer-Reynolds, 2005). Soh (2015) conducted a study including 34 faculty members and 202 students and discovered that demographic characteristics such as gender, age, academic degree, and teaching experience were not associated with the creativity nurturing behaviours of teachers. When Walsh and Hardy (1999) compared academic programmes in relation to gender from Facione's California Critical Thinking Disposition Inventory, they found that females scored better than males. A study on creative ability by Zetriuslita et al. (2016) found that there were gender differences as men possessed creative abilities than women. According to the study by Bagheri and Ghanizadah (2016), no differences were found between men and women in creative thinking. Asked to rate their creativity, family toughness, and emotional intelligence, Chan (2005) discovered that there were no differences between men and women in any of the measured creative constructs.

According to Soh (2015), it is well known that teachers have a major impact on the inventiveness of students. Teachers' responses to their students' ideas, perspectives, and proposals can be anticipated to influence the students' ensuing determination and propensity in generating fresh ideas, viewpoints, and suggestions. In essence, positive teacher responses will naturally motivate students to work hard, while premature and unfavourable teacher reactions will dampen students creative discovery. Simply put, teachers can nurture creativity in their students if they demonstrate creative behavior frequently with students on a daily basis. It is also true that not all teachers have capacity-building behaviours. The effect of their behavior on their kids' creativity is possible but unknown. Therefore, they must know their impact on student creativity and be trained to show creativity-inducing behaviours in the learning situation.

\section{METHODOLOGY}

\section{Research Design}

The study employed a quantitatively based cross-sectional survey design. This design was appropriate because statistical inferences were made on the data collected from the respondents. In using this design, respondents were not manipulated, but data about their creativity were gathered. The choice of this design aligns with the views of Allen (2017) and Ihudiebube-Splendor and Chikeme (2020) that cross-sectional survey designs are employed to describe a population of interest at a specific point in time. Validly, cross-sectional survey designs are used when researchers want to record information without manipulating variables. Again, cross-sectional survey designs survey a large number of people at one moment in time to define characteristics of that population such as age, gender, and geographic location among other factors. These examinations may usually be completed in a short time and are reasonably affordable. However, cross-sectional survey designs cannot establish causal correlations among variables because measurement is performed in a snapshot (Allen, 2017; IhudiebubeSplendor \& Chikeme, 2020).

\section{Participants}

The researcher surveyed 768 out 1,321 in-service teachers pursuing post-diploma teaching programmes on satellite campuses (across the five belts of Ghana: southern, northern, eastern, central, and western) of the University of Cape Coast, Ghana. These satellite campuses are strategically placed to provide all in-service teachers with an opportunity to upgrade to the degree level as the minimum qualification for teaching in Ghana. In this sense, the respondents were drawn from all parts of Ghana and their number was appropriate and adequate to draw inferences about teachers and the creative nurturing behaviors of teachers in Ghana. The respondents were both male $(\mathrm{n}=375)$ and female $(\mathrm{n}=393)$. The respondents had teaching experience between 1 and 20 years. 


\section{Instruments}

Data for the study were collected using an adapted version of the Sharma and Sharma (2018) creativity nurturing behavior scale (15items; $\alpha=.79)$. Samples of statements on the scale are "I regularly give group assignments as part of the pedagogy" and "I do not react immediately to the suggestions of the students rather give them time". The scale was scored based on agreement to disagreement (1-4). The scale was piloted among 40 randomly selected in-service teachers in the Cape Coast Metropolis, where preliminary analysis provided a solid internal consistency of 0.76 . This internal consistency meets most criteria, especially Ritter (2010), that the reliability coefficient between 0.6 above for a measurement scale is deemed appropriate for data gathering.

\section{Data Analysis}

The data collected with the instruments were analyzed using descriptive statistics and inferential statistics. The descriptive statistics used were frequencies and percentages to quantify the respondents based on their levels of creative nurturing behaviors. The inferential statistics used were independent samples t-test and One-Way Analysis of Variance (ANOVA). The independent samples t-test was used because the research compared responses of males and females, while the one-way ANOVA was used because the researcher compared responses based on the experience of teachers on creative nurturing behaviors.

\section{RESULTS}

The data collected were cleaned and assumptions were tested to give way for the analysis. Fundamentally, assumptions such as normality and homogeneity tests were met. The study was about creative nurturing behaviors exhibited by in-service teachers in the process of executing their in-service mandate. These creativity-feeding behaviors of in-service teachers were measured using a 15 -item scale with four (4) dimensions; abstraction, inquisitiveness, motivation, and critical thinking. In each dimension, the researcher examined the levels of creativity-fostering behaviors to ascertain which areas of creativity in learners were adequately honed by teachers and which areas the teachers lacked and needed to be guided through creative workshops.

Table 1 shows the results on the levels of creativity-promoting behaviors among in-service teachers based on the scale dimensions and the total scale. Regarding abstraction as dimension one, the study revealed that the majority of the in-service teachers possess low levels. This implies that teachers may find it difficult to teach students using abstract strategies such as assignments, group work, and, as well, soliciting views from the students. Regarding inquisitiveness as dimension two, the study revealed that the majority of the in-service teachers possess moderate levels. This implies that in way one or the other teachers provide opportunities for students to share ideas and thoughts, students are understood by teachers, and as well, teachers try to track the progress of their students. Regarding motivation as dimension three, the study revealed that the majority of the in-service teachers possessed moderate levels. This implies that teachers try making efforts to inspire their students in terms of encouragement, emphasizing the importance of the information taught and as well making time to listen to students who may be distressed. Regarding critical thinking as dimension four, the study revealed that the majority
Table 1. Levels of teacher creativity nurturing behaviour $(\mathrm{n}=768)$

\begin{tabular}{|c|c|c|c|}
\hline Levels & Score range & Frequency & Percentage \\
\hline \multicolumn{4}{|c|}{ Creative abstraction (4-items) } \\
\hline Lowest level & $4-12$ & 380 & 49.5 \\
\hline Moderate level & $13-20$ & 183 & 23.8 \\
\hline The highest level & $21-28$ & 205 & 26.7 \\
\hline \multicolumn{4}{|c|}{ Creative inquisitive (3-items) } \\
\hline Lowest level & $3-9$ & 122 & 15.9 \\
\hline Moderate level & $10-15$ & 395 & 51.4 \\
\hline The highest level & $16-21$ & 251 & 32.7 \\
\hline \multicolumn{4}{|c|}{ Creative motivation (3 items) } \\
\hline Lowest level & $3-9$ & 264 & 34.4 \\
\hline Moderate level & $10-15$ & 403 & 52.4 \\
\hline The highest level & $16-21$ & 101 & 13.2 \\
\hline \multicolumn{4}{|c|}{ Creative critical thinking (4-items) } \\
\hline Lowest level & $4-12$ & 415 & 54.0 \\
\hline Moderate level & $13-20$ & 353 & 46.0 \\
\hline The highest level & 21-28 & 0 & 0 \\
\hline \multicolumn{4}{|c|}{ Total creativity nurturing behaviours of teachers } \\
\hline Lowest level & $15-45$ & 302 & 39.3 \\
\hline Moderate level & $46-75$ & 267 & 34.7 \\
\hline The highest level & $76-105$ & 199 & 26.0 \\
\hline
\end{tabular}

Source: Field data (2021)

Table 2. Gender difference in the creativity-supporting behaviors of teachers

\begin{tabular}{lllllllllll}
\hline Gender Sample & Mean & SD & t & df & Sig. & F & LCI & UCI & p
\end{tabular}

\begin{tabular}{lllllllllll}
\hline Male & 375 & 49.37 & 5.53 & .874 & 766 & 0.448 & .575 & -.414 & 1.080 & .382 \\
\hline
\end{tabular}

\begin{tabular}{llll}
\hline Female & 393 & 49.04 & 5.01
\end{tabular}

Source: Field data (2021)

of the in-service teachers possessed low levels of critical thinking abilities as they make less effort in nurturing students in this respect. In this sense, teachers may find it impossible to apply the teaching in different contexts, be less motivated to teach students to transfer knowledge, might not solicit ideas from students, and as well evaluate or give judgments on contributions of students in class. In general, inservice teachers possessed low levels of creativity nurturing behaviours. These findings paint a gloomy picture of young people being taught by these teachers because areas that could propel them to explore academically are less catered for by their teachers. In one way, it might not be the fault of teachers not possessing adequate knowledge in creativity so that they could channel such abilities into their teaching, but because political infiltration has made teacher training institutions drift from objectivity to subjectivity.

The study considered gender differences between teachers in service regarding their creativity-inspiring behaviors. Table 2 shows the results of the independent samples t-test concerning male and female in-service teachers' differences in creativity nurturing behaviour. Based on the results, it is evident that equal variances were assumed as Levene's test of equality of variance produced a sig. value of 0.448 greater than the threshold of.05. In search of differences, it was found that there were no significant differences between males $(\mathrm{n}=375$, $\mathrm{M}=49.37$, and $\mathrm{SD}=5.53)$ and females $(\mathrm{n}=393, \mathrm{M}=49.04, \mathrm{SD}=5.01$, $\mathrm{t}(766)=.874$, and $\mathrm{p}=.382$ ) in-service teachers with respect to their nurturing behavior of creativity. The effect size for the nonsignificant differences between male and female in-service teachers $(\mathrm{MD}=.333$ and $95 \% \mathrm{CI}=-.414$ to 1.080 ) was moderate at 0.06 according to Cohen (1988). This implies that $6 \%$ of the variance in the creativity nurturing behaviours was represented by the gender of the in-service teachers. 
The study considered differences in the teaching experience of inservice teachers as they reflect in creativity nurturing behaviours. The teaching experiences of the in-service teachers were in four categories against one continuous variable. Based on the nature of the variable combinations, One-Way ANOVA was appropriate for the analysis. In examining the results of One-Way ANOVA, it was found that homogeneity of variance was violated as Levene's test of equality of variance produced a sig. value of 0.034 less than the threshold of.05. This could have occurred as a result of the huge differences between the categories of teaching experiences of the in-service teachers. However, this was compensated for by the Welch results, which were greater than.05. Furthermore, examination of the ANOVA results revealed that there were no significant differences in the creativity nurturing behaviors of the teachers regarding their teaching experience, thus $F(3$, $33.49)=2.59$ and $\omega=.069$. The results show that teachers in service who have taught for a period of 6-10 years $(\mathrm{n}=214, \mathrm{M}=49.51, \mathrm{SD}=4.95$; and $95 \% \mathrm{CI}=48.02$ to 49.56$) 11-15$ years $(\mathrm{n}=24, \mathrm{M}=45.96, \mathrm{SD}=7.14$; and $95 \%$ $\mathrm{CI}=42.95$ to 48.97 ) were not different in the nurturing of creativity of students than those who have taught for 1-5 years $(n=520, M=49.51$, $\mathrm{SD}=4.95 ; 95 \% \mathrm{CI}=49.08$ to 49.94$)$ and $16-20$ years $(\mathrm{n}=10, \mathrm{M}=49.20$, $\mathrm{SD}=5.27 ; 95 \% \mathrm{CI}=48.83$ to 49.58 ). The magnitude of the difference was small with an effect size of .1 according to Cohen (1988). This implies that $1.0 \%$ of the variance in the creativity nurturing behaviours was represented by the teaching experience of the in-service teachers.

\section{DISCUSSION}

The study aimed to examine the levels of creativity nurturing ability of in-service teachers and to find out if differences could be found based on in-service teachers' gender and teaching experience. The study revealed that most teachers had low levels of creativity nurturing behaviours. With this, in-service teachers might not be able to nurture students to become creative in their learning. The revelation portrays a blurry picture of the teachers as their show of inadequacy could hamper their progress in the ever-changing educational landscape. This inadequate creativity nurturing behaviours exhibited by in-service teachers defeat the propagation by OECD (2009) that teachers need to be creative as it is critical to prepare students for the unknown: for jobs that do not yet exist, for technologies that have not yet been conceived, and for issues that have not yet been foreseen. The revelation was inconsistent with the idea that teachers with adequate creative abilities inure teacher-student interaction (Sawyer, 2012). Furthermore, the revelation debunks the assertion that $21^{\text {st }}$-century teaching and learning requires teaching with creative abilities so that they could foster creativity and critical thinking in learners (Bloom \& Doss, 2019).

Again, the study revealed that male and female in-service teachers had low levels of creativity nurturing behaviors, as their mean scores from the independent samples t-test were approximately the same. Without any doubt, the finding is not far-fetched because both sexes passed through the old way of training learners and were engaged for new ways of teaching using creative ideas and strategies. The finding of the current study is not in the harmony with a similar one that found significant differences between male and female teachers in their creative abilities, according to Zetriuslita et al. (2016). However, the current study's finding corroborates with Chan (2005) and Torrance (1983) study findings. In their studies, they found no significant differences between men and women in creative abilities.
Finally, the study did not reveal statistically significant differences in the creative nurturing behaviors of the in-service teachers based on their teaching experience. This seems unsurprising because these teachers were recruited from similar teacher training institutions in Ghana, where such institutions appear not to be training teachers with contents related creativity. More so, the less experienced teachers could be more equipped in creative teaching than more experienced teachers because most teacher training institutions in Ghana appear to be adjusting to the new paradigm of teaching that falls within the realms of new standard-based curriculum, where some of these teachers were trained since 2017. The study revelation in part supports and refutes some empirical studies. For instance, Dikici (2014) study found that teachers with less experience have a good attitude toward creative thinking and creative teaching than more experienced colleagues while Huang et al.'s (2019) and Taat and Suki's (2021) studies found that teachers with more experience showed high creativity and originality than teachers with less experience.

\section{CONCLUSIONS}

The study investigated the in-service teachers' creativity nurturing behaviours and found that most of them measured low in this allimportant natural ability. Comparing the low ability of the creativity nurturing ability of these teachers against their gender and experience, teachers' gender and experience had no role in their creativity nurturing behaviours.

\section{Implication for Policy Direction and Practice}

It is imperative to note that these low levels of creative nurturing behaviors found could bring about less academic reasoning on the part of teachers and those they teach because creativity shares great features with reasoning or imagination. With this, in-service teachers might find it difficult to idealize their thoughts because they have fewer abilities in doing that, hence no innovations in their practice as professional teachers despite the availability of creative guides like a new standard-based curriculum. To this end, it is important that the Government of Ghana, through its educational stakeholders such as the Ministry of Education, the Ghana Education Service, and the National Council for Curriculum Assessment (NaCCA), make it a point to offer an intensive gradual curriculum retraining for all in-service teachers under their supervision for a period not less than an academic year. This can be done at the various circuit capitals of the educational categorization in Ghana. With this, resident trainers could be used as a way of decentralizing the training process. When this is considered, the benefits far outweigh any cost that would be incurred because no trainer would be moved from his or her comfort zone to any remote area that requires a lot of preparation and financial resources. It is imperative to note that the less adequacy of creative abilities among in-service teachers is unfathomable and unexpected. Under normal circumstances, the more experienced teachers should serve as mentors to the less experienced ones by seniority but that was not the case. To change the narrative, the Ghana Education Service should develop incentive packages to award teachers who exhibit acts of creativity in their professional practice so that they do not regress as they accumulate more years in the job. Doing this would reinforce teachers with the need to broaden their knowledge horizon and prepare them psychologically for any eminent curriculum change in the future. 
Funding: The author received no financial support for the research and/or authorship of this article.

Declaration of interest: Author declares no competing interest.

Data availability: Data generated or analysed during this study are available from the author on request.

\section{REFERENCES}

Abudu, A. M. (2015). Basic school teachers 'perceptions about curriculum design in Ghana. International Journal of Educational Studies, 2(2), 59-69.

Ahmadi, N., Peter, L., Lubart, T., \& Besançon, M. (2019). School environments: Friend or foe for creativity education and research? In C. A. Mullen (Ed.), Creativity under duress in education? (pp. 255266). Springer. https://doi.org/10.1007/978-3-319-90272-2_14

Aljughaiman, A., \& Mowrer-Reynolds, E. (2005). Teachers' conceptions of creativity and creative students. The Journal of Creative Behaviour, 39(1), 17-34. https://doi.org/10.1002/j.21626057.2005.tb01247.x

Allen, M. (2017). The SAGE encyclopedia of communication research methods. SAGE. https://doi.org/10.4135/9781483381411

Al-Nouh, N. A., Abdul-Kareem, M. M., \& Taqi, H. A. (2014). Primary school EFL teachers' attitudes towards creativity and their perceptions of practice. English Language Teaching, 7(9), 74-90. https://doi.org/10.5539/elt.v7n9p74

Andriopoulos, C. A. (2000). Mind stretching: A grounded theory for enhancing organisational creativity [Doctoral dissertation, University of Strathclyde].

Apak, J., Taat, M. S., \& Suki, N. M. (2021). Measuring teacher creativity-nurturing behavior and readiness for 21 st century classroom management. International Journal of Information and Communication Technology Education, 17(3), 52-67. https://doi.org/10.4018/IJICTE.20210701.oa4

Apau, S. K. (2021). Teachers concerns about the implementation of the standard-based curriculum in Ghana: A case study of Efutu Municipality. Educational Research and Reviews, 16(5), 202-211. https://doi.org/10.5897/ERR2020.4051

Bagheri, F., \& Ghanizadah, A. (2016). Critical thinking and gender differences in academic self-regulation in higher education. Journal of Applied Linguistics and Language Research, 3(3), 133-145.

Baruah, J., \& Paulus, P. B. (2019). Collaborative creativity and innovation in education. In C. A. Mullen (Ed.), Creativity under duress in education? (pp. 155-177). Springer. https://doi.org/ 10.1007/978-3-319-90272-2_9

Beghetto, R. A. (2007). Ideational code-switching: Walking the talk about supporting student creativity in the classroom. Roeper Review, 29(4), 265-270. https://doi.org/10.1080/02783190709554421

Beghetto, R. A., \& Kaufman, J. C. (2010). Broadening conceptions of creativity in the classroom. In R. A. Beghetto, \& J. C. Kaufman (Eds.), Nurturing creativity in the classroom (pp. 191-205). Cambridge University Press. https://doi.org/10.1017/CBO9780511781629. 010

Beghetto, R. A., \& Kaufman, J. C. (Eds.). (2010). Nurturing creativity in the classroom. Cambridge University Press. https://doi.org/ 10.1017/CBO9780511781629
Birdi, K. S. (2016). Creativity training. In P. Sparrow, H. Shipton, P. Budhwar, \& A. Brown (Eds.) Human resource management, innovation and performance. Palgrave Macmillan. https://doi.org/10.1057/ 9781137465191_19

Bloom, L. A., Doss, K. K., Sastre, C., \& Martin, T. H. (2019). The effects of models and instructions on children's divergent thinking. Gifted and Talented International, 34(1-2), 44-58. https://doi.org/10.1080/ 15332276.2019.1693312

Chan, S., \& Yuen, M. (2015). Teachers' beliefs and practices for nurturing creativity in students: Perspectives from teachers of gifted students in Hong Kong. Gifted Education International, 31(3), 200-213. https://doi.org/10.1177/0261429413511884

Collard, P., \& Looney, J. (2014). Nurturing creativity in education. European Journal of Education, 49(3), 348-364. https://doi.org/ 10.1111/ejed.12090

Cropley, A. J. (1997). Fostering creativity in the classroom: General principles. The Creativity Research Handbook, 1, 83-114.

Davies, D., Jindal-Snape, D., Collier, C., Digby, R., Hay, P., \& Howe, A. (2013). Creative learning environments in education: A systematic literature review. Thinking Skills and Creativity, 8, 80-91. https://doi.org/10.1016/j.tsc.2012.07.004

Dikici, A. (2014). Relationships between thinking styles and behaviors fostering creativity: An exploratory study for the mediating role of certain demographic traits. Educational Sciences: Theory and Practice, 14(1), 179-201. https://doi.org/10.12738/estp.2014.1.1939

Doyle, C. L. (2019). Speaking of creativity: Frameworks, models, and meanings. In C. A. Mullen (Ed.), Creativity under duress in education? (pp. 41-62). Springer. https://doi.org/10.1007/978-3-319-902722_3

Fasko, D., \& Rizza, M. G. (2019). Role of creativity in educational systems and the change process. In C. A. Mullen (Ed.), Creativity Under Duress in Education? (pp. 383-398). Springer. https://doi.org/ 10.1007/978-3-319-90272-2_20

Florida, R. (2004). The rise of the creative class and how it's transforming work, leisure, community, and everyday life. Brilliance Audio.

Gong, Y., Cheung, S. Y., Wang, M., \& Huang, J. C. (2012). Unfolding the proactive process for creativity: Integration of the employee proactivity, information exchange, and psychological safety perspectives. Journal of Management, 38(5), 1611-1633. https://doi.org/10.1177/0149206310380250

Hargreaves, A. P., \& Shirley, D. L. (Eds.). (2009). The fourth way: The inspiring future for educational change. Corwin Press.

Hong, E., Hartzell, S. A., \& Greene, M. T. (2009). Fostering creativity in the classroom: Effects of teachers' epistemological beliefs, motivation, and goal orientation. The Journal of Creative Behaviour, 43(3), 192-208. https://doi.org/10.1002/j.2162-6057.2009.tb01314. $\mathrm{X}$

Huang, X., Lee, J. C. K., \& Dong, X. (2019). Mapping the factors influencing creative teaching in mainland China: An exploratory study. Thinking Skills and Creativity, 31, 79-90. https://doi.org/ 10.1016/j.tsc.2018.11.002

Ihudiebube-Splendor, C. N., \& Chikeme, P. C. (2020). A descriptive crosssectional study: Practical and feasible design in investigating health careseeking behaviors of undergraduates. SAGE. https://doi.org/10.4135/ 9781529742862 
Karpudewan, M., \& Meng, C. K. (2017). The effects of classroom learning environment and laboratory learning environment on the attitude towards learning science in the 21st-century science lessons. Malaysian Journal of Learning and Instruction, 6, 25-45. https://doi.org/10.32890/mjli.2017.7795

Karwowski, M., Lebuda, I., Wisniewska, E., \& Gralewski, J. (2013). Big five personality traits as the predictors of creative self-efficacy and creative personal identity: Does gender matter? The Journal of Creative Behavior, 47(3), 215-232. https://doi.org/10.1002/jocb.32

Lee, S. Y., Florida, R., \& Acs, Z. (2004). Creativity and entrepreneurship: A regional analysis of new firm formation. Regional Studies, 38(8), 879-891. https://doi.org/10.1080/ 0034340042000280910

Loogma, K., Kruusvall, J., \& Umarik, M. (2012). E-learning as innovation: Exploring innovativeness of the VET teachers' community in Estonia. Computers \& Education, 58, 808-817. https://doi.org/10.1016/j.compedu.2011.10.005

Ministry of Education [MoE]. (2018). National pre-tertiary education curriculum framework for developing subject curricula. https://nacca.gov.gh/wp-content/uploads/2019/04/National-Pretertiary-Education-Curriculum-Framework final.pdf

National Council for Curriculum and Assessment [NaCCA]. (2019). Cross-Curriculum Issues. https://nacca.gov.gh/?page_id=8632

Nemeržitski, S., Loogma, K., Heinla, E., \& Eisenschmidt, E. (2013). Constructing a model of teachers' innovative behaviour in school environment. Teachers and Teaching, 19(4), 398-418. https://doi.org/10.1080/13540602.2013.770230

OECD. (2009). The case for 21st-century learning. http://www.oecd.org/ general/thecasefor 21 st-centurylearning.htm

Okoth, T. A. (2016). Challenges of implementing a top-down curriculum innovation in English language teaching: Perspectives of form 2 English language teachers in Kenya. Journal of Education and Practice, 7(3), 169-177. https://doi.org/10.1080/13540602.2013 .770230

Ritter, N. L. (2010). Understanding a widely misunderstood statistic: Cronbach's "Alpha" [Paper presentation]. Annual Meeting of the Southwest Educational Research Association, New Orleans, February 18, 2010.

Ritter, S. M., Gu, X., Crijns, M., \& Biekens, P. (2020) Fostering students' creative thinking skills by means of a one-year creativity training program. PLoS ONE, 15(3), e0229773. https://doi.org/10.1371/ journal.pone.0229773

Sahlberg, P. (2010). Rethinking accountability in a knowledge society. Journal of Educational Change, 11(1), 45-61. https://doi.org/10.1007/ s10833-008-9098-2
Saibon, J., Syed Abdullah, S. M., \& Leong, A. C. H. (2017). Effectiveness of creative pedagogy in enhancing the knowledge and awareness on bullying amongst secondary school students. Advances in Social Science, Education and Humanities Research, 133, 160-165.

Sawyer, K. (2012). Extending sociocultural theory to group creativity. Vocations and Learning, 5(1), 59-75. https://doi.org/10.1007/s12186 $-011-9066-5$

Sharma, E., \& Sharma, S. (2018). Creativity nurturing behaviour scale for teachers. International Journal of Educational Management, 32(6), 1016-1028. https://doi.org/10.1108/ijem-10-2017-0294

Snell II, A. H. (2013). Creativity in instrumental music education: A survey of winds and percussion music teachers in New York State. University of Rochester.

Soh, K. (2015). Creativity fostering teacher behaviour around the world: Annotations of studies using the CFTIndex. Cogent Education, 2(1), 10-34. https://doi.org/10.1080/2331186X.2015. 1034494

Soh, K. (2017). Fostering student creativity through teacher behaviors. Thinking Skills and Creativity, 23, 58-66. https://doi.org/10.1016/ j.tsc.2016.11.002

Stone, D. L. (2015). Art teachers' beliefs about creativity. Visual Arts Research, 41(2), 82-100. https://doi.org/10.5406/visuartsrese.41.2. 0082

Turner, S. (2013). Teachers' and pupils' perceptions of creativity across different key stages. Research in Education, 89(1), 23-40. https://doi.org/10.7227/RIE.89.1.3

Ucus, S., \& Acar, I. H. (2018). Teachers' innovativeness and teaching approach: The mediating role of creative classroom behaviors. Social Behaviour and Personality: An International Journal, 46(10), 1697-1711. https://doi.org/10.2224/sbp.7100

Voogt, J., \& Roblin, N. P. (2012). A comparative analysis of international frameworks for $21 \mathrm{st}$ century competences: Implications for national curriculum policies. Journal of Curriculum Studies, 44(3), 299-321. https://doi.org/10.1080/00220272.2012. 668938

Walsh, C., \& Hardy, R. (1999). Dispositional differences in critical thinking related to gender and academic major. Journal of Nursing Education, 38, 149-155. https://doi.org/10.3928/0148-483419990401-04

Zetriuslita, H. J., Ariawan, R., \& Nufus, H. (2016). Students' critical thinking ability: Description based on academic level and gender. Journal of Education and Practice, 7(12), 154-164. 